\title{
Digital Literacy Levels in ASEAN (Comparative Study on ASEAN Countries)
}

\author{
Ayu Kusumastuti ${ }^{1}$, Astrida Fitri Nuryani ${ }^{2}$ \\ \{ayukusumastuti@ub.ac.id ${ }^{1}$, astridafn@ub.ac.id² \\ Universitas Brawijaya, Indonesia ${ }^{1,2}$
}

\begin{abstract}
This paper would attempt at explaining the digital literacy levels among ASEAN (Association of Southeast Asian Nations) countries, how their awareness in this aspect emerged, and their causes. In their entrance into the 4.0 revolution, ASEAN countries experienced an increase in digital literacy levels, especially since. Countries with a high level of digital literacy maintained their policies and programs whereas countries with a low level of digital literacy expected to improve by implementing better programs and putting forward digital literacy aspects as their main policy. Digital literacy level among ASEAN countries is not different from one another. Nevertheless, the level of digital literacy can be ranked by mean rank from 1 to 8 that sequence is Singapore (24.6), Thailand (24.0), Indonesia (20,5), Vietnam (20.4), Myanmar (19,90), Philippines (19.80), Malaysia (19.20) and Cambodia (15.6). The calculation of the Kruskal Wallis Test shows a significant number, that is 0.957 . In conclusion, our H1 was rejected, which we interpreted as no difference from digital literacy levels among ASEAN countries. These were caused by information literacy, technology literacy, and media literacy of ASEAN countries which were almost at the same level. ASEAN countries had the capacity to produce digital content, to adopt new technology, to manage media information and to adopt technology in certain situations.
\end{abstract}

Keywords: Digital Literacy, ASEAN, 4.0 Revolution, the Internet.

\section{Introduction}

The entry of the internet changes patterns in society. Especially in ASEAN, the presence of technology has begun to create an application-based economic system that changes the structure of the society. For example the presence of Uber and Gojek in Indonesia, Singapore and Vietnam threatened conventional transportation systems. In the community itself, it is certainly inseparable from the pros and cons of the phenomenon. There are groups of people who are able to use and utilize technology so that they benefit, but there are also those who fail to adapt. With the development of technology, of course the community will further develop themselves if he is able to adapt to technology. It is hoped that the community will be able to utilize the technology to its full potential so as to be able to develop themselves, groups or even countries in various sectors. Therefore measurement of the level of "literacy" technology or further in this study is called digital literacy is important to do. Measurement of this can be used as a reference in determining policy and community response itself in response to the development of the digital world. Measuring by ranking at the state level can find out the position of one country to another as well as knowing the conditions of the level of "read and write" society for everything related to technology and digitalization. Multiple 
researches on digital literacy have been carried out. Chetty (2018) explains the need to make an internationally accepted measurement of digital literacy index [1]. The index also reflects the development of a country's digital economy.

In the Philippines, there are activities to improve community digital literacy through projects. For example, Code Phil is a youth organization to empower youth through digital literacy [2]. Brunei Darussalam is also a country that has priority to improve infrastructure related to connectivity and in Myanmar there are research activities for digital literacy for managerial level executives.

From various phenomena regarding digital literacy, the writer wants to rank and to compare one country with other countries in ASEAN regarding the level of digital literacy. This is because countries in ASEAN have issued many programs related to this, of course comparing the level of digital literacy with one another becomes a start to find out how many country programs and public awareness of digital literacy have been built. Thus, a country that has a high level of digital literacy can maintain its policies and programs while a country that has a low level of digital literacy is expected to improve programs and policies that prioritize this aspect. For this reason, research on this subject is interesting to do, and at the same time it is displaying scientific knowledge about the study of the ASEAN region in knowing the development of society in the digital and technological fields. The purpose of this study is to measure the difference in digital literacy levels of ASEAN countries: Cambodia, Indonesia, Malaysia, Myanmar, Philiphine, Singapore, Thailand and Vietnam.

\section{Materials}

Digital literacy literally means one's ability to understand, process, and process digitalbased information. Digital literacy is the awareness, attitude, and ability of individuals to use digital devices and facilities appropriately to identify, access, manage, integrate, evaluate, analyze, and synthesize digital resources, build new knowledge, create media of expression, and communicate with others, in the context of certain situations, to activate constructive social actions and think about the pros and cons. High media literacy is characterized by: 1) critical power in receiving and interpreting messages, 2) the ability to search and verify messages, 3) the ability to analyze messages in a discourse, 4) understand the logic of creating reality by the media, 5) the ability to construct positive messages and distribute it to other parties [3].

This digital literacy is very dynamic, has a standard that changes both the dimensions of time, place, and culture, along with the development of the digital world. This digital literacy inequality causes gaps in terms of accessing or using information technology among people, demographic groups, or countries and this is often related to the socio-economic situation of a region. For example, as of January 2015, active internet users around the world were only around $42 \%$, Canada ranked first with a percentage of $93 \%$, while India was at the bottom with an internet usage rate of $19 \%$ [4].

Overall, in media studies and across different disciplines, digital literacy is still roughly defined. However, according to Chetty (2018) digital literacy comprises at least 5 dimensions and 3 perspectives; namely the dimensions of information literacy, computer literacy, media alliteration, communication literacy and literacy technology. Each dimension consistes of 3 perspectives, namely technical, cognitive and ethical. Information literacy is the ability to search, retrieve, manipulate, produce, synthesize and critique and use appropriate digital 
content. Computer literacy refers to the ability to understand, operate, to evaluate its work, to understand proper use (respect the privacy of fellow tool users) of hardware and software.

Media literacy includes the ability to interact, discover, manipulate, use information, to assess the truth of information, to manage information flow appropriately from textual media, sound, images and videos. Literacy communication includes the ability to communicate one to one or one to many to broadcast content, understand the form of communication that is appropriate to meet current challenges, the right use in operating email, telephone or message levels at the individual, organizational or public level. Literacy technology refers to a person's ability to adopt technology for certain situations, knowing which tools are appropriate, the ability to create new digital products / services / technology in a modern economy while also being able to think critically to solve economic / business problems through digital tools and knowledge for the development and maintenance of appropriate tools / technology.

A high level of digital literacy means that people have knowledge / cognitive, technical and ethical skills in accessing, using, synthesizing, evaluating, criticizing, creating and developing digital content, software \& hardware, text, media, sound, video, social media, digital interaction \& communication and good digital tools / technology. With digital literacy, it is possible for people to be able to empower themselves to participate in various sectors. Revolution and globalization 4.0 is a new revolution in society where individuals from every corner of the world can be empowered through the internet and other digital devices. In the process of revolution and globalization 4.0 this is slightly different from the pattern of the previous revolution. Within stages of globalization 1.0 and 2.0 economic unification and capitalization work under international economic institutions, multi-national corporations that often originate from the first world (western) countries, but globalization 3.0 and globalization 4.0 have now changed their patterns. With the discovery of the internet, the economic structure for example has begun to be filled by new start-up businesses. This reflected that the existence of technology, the internet and other digital devices is able to provide the potential of everyone in this field to develop various sectors of life (economic, social, political) and it is possible to begin shifting the roles of large companies .

ASEAN (Association of South East Asian Nations) is a regional association of countries in Southeast Asia consisting of 10 countries that cooperate together in social, economic, political, educational, security and military aspects as well as culture. Several problems arise in ASEAN countries when entering the digital economy including weak business in building networks / broadband, the existence of several regulations that support e-commerce innovation, low awareness and consumer confidence in digital sales systems, and limited local content supply [5]. But the countries in ASEAN have attempted to solve the problems. Countries in ASEAN have done a lot of activities related to the improvement of knowledge / cognitive, technical and ethical skills in accessing, using, synthesizing, evaluating, criticizing, creating and developing digital content. The Philippines initiated the Code Phil project of a youth organization to empower youth through digital literacy. Brunei Darussalam is also a country that prioritizes infrastructure improvement related to connectivity. Meanwhile, in Myanmar there are research activities for digital literacy for managerial level executives.

In Chetty (2018)'s Bridging the Digital Literacy Divide: Digital Measuring Literacy, it is mentioned there are efforts in overcoming the digital divide between the G20 countries (economic associations of countries and developing countries). It was further explained that to overcome this, the G20 must identify digital literacy in various perspectives in order to achieve a modern digital economy. For this reason, the G20 must prepare itself in facing the modern economy's challenges by providing various training and educational programs. Chetty 
(2018)'s research easel on the basis of the author to measure the level of digital literacy in ASEAN countries. This measurement is important because many countries do not know which position their digital literacy level is so they do not understand the country's productivity level. Therefore, literacy measurements with instruments that have been designed by researchers are also a reference in conducting analysis.

From Kearney (2017), we discovered that ASEAN policy aims to become the vanguard of the digital economy and as a globally competitive region. Therefore, ASEAN has high digital development potential marked by the ownership of the smartphone community and two-fifths of its people are always online. The internet is growing and also connecting with many merchants, consumers and families. ASEAN digital economy generates profits of $\$ 150$ billion every year 2) ASEAN 2025 policy allows this region to become a leading region in the digital economy due to: the increasing cashless society (people who use a lot of non-cash money). This is very beneficial because more and more people are participating in the digital economy, where payments are secure, direct and standardized. The emergence of Smart City, namely the development of cities that utilize information technology; the emergence of industry 4.0 which is characterized by digitalization in all respects, such as digitalization in products and services, digitizing customer involvement and digitizing to increase productivity; increasingly fast and efficient public services; and the emergence of a digital generation (generation capable of technology).

\section{Research Methods}

Since we implement quantitative research based on secondary data, which are then compared with contexts from several ASEAN countries. We define quantitative research as the type research that uses numerical data as a basis for analysis. We proceed to analyze the data in 3 main ways, namely survey data, secondary data and intervening / intervention [6]. In this study known research variables namely the level of digital literacy. There are 4 indicators to measure this, namely computer literacy, media literacy, communication literacy and technology literacy. Each indicator is elaborated on questions referred to in the 2018 Inclusive Internet Index data.

We obtain our data from The 2018 Inclusive Internet Index, as compiled and analyzed by the Economist Intelligence Unit (EIU) in collaboration with Facebook. The dataset is available on their website. The data display the Internet Inclusive Index in all countries of the world. Indicators to measure the index are Availability, Affordability, Relevance and Readiness. To measure the index, a survey was conducted on 4,267 respondents from 85 countries with data from the Global Value Internet Survey. This index functions as a measurement on perceptions about how internet usage affects people's lives. We subsequently study the data from the Economist Intelligence Unit (EIU). Studying this data is one of the secondary data collection techniques for sorting data that is in line with the focus of the study. We subsequently choose the appropriate indicators in measuring and comparing the level of digital literacy of countries in ASEAN.

In this study several steps carried out by researchers are:

1. Obtaining the analyzed data source from the 2018 Inclusive Internet Index in collaboration with Facebook.

2. The data used is derived from several questions to measure the level of digital literacy with indicators of information literacy research, computer literacy, media literacy, 
communication literacy and literacy technology. Some of these questions come from the indicators of Availability, Affordability, Relevance and Readiness.

Table 1. Digital Literacy Indicators

\begin{tabular}{|c|c|c|}
\hline $\begin{array}{c}\text { Digital Literacy Level } \\
\text { Indicator }\end{array}$ & Item Question & Measurement Description \\
\hline Information literacy & $\begin{array}{l}\text { Internet users } \\
\text { Mobile subscriber } \\
\text { E-commerce content } \\
\text { Availability of local languange } \\
\text { Value of e finance } \\
\text { Value of e health } \\
\text { Value of e commerce } \\
\text { Level of literacy }\end{array}$ & $\begin{array}{l}\text { The state can provide } \\
\text { adequate tools so that } \\
\text { people can search, } \\
\text { retrieve, manipulate, } \\
\text { produce, synthesize and } \\
\text { criticize digital content }\end{array}$ \\
\hline $\begin{array}{l}\text { Computer literacy } \\
\text { (software and } \\
\text { hardware) }\end{array}$ & $\begin{array}{l}\text { Fixed broadband line } \\
\text { Average mobile upload } \\
\text { Average mobile download } \\
\text { Average mobile latency } \\
\text { Privacy regulation }\end{array}$ & $\begin{array}{l}\text { Countries can provide } \\
\text { adequate tools so that } \\
\text { people can understand, } \\
\text { operate, evaluate their } \\
\text { work, understand proper } \\
\text { use (respecting the privacy } \\
\text { of fellow tool users) of } \\
\text { hardware and software }\end{array}$ \\
\hline $\begin{array}{l}\text { Media literacy (text, } \\
\text { sound, image, video) }\end{array}$ & $\begin{array}{l}\text { Availability of basic info } \\
\text { Trust in government website } \\
\text { Trust in non-government website } \\
\text { Trust in social media } \\
\text { E commerce safety }\end{array}$ & $\begin{array}{l}\text { The ability of people to } \\
\text { interact, discover, } \\
\text { manipulate, use } \\
\text { information, assess the } \\
\text { truth of information, } \\
\text { manage information flow } \\
\text { appropriately from textual } \\
\text { media, sound, images and } \\
\text { videos. }\end{array}$ \\
\hline $\begin{array}{l}\text { Communication } \\
\text { literacy (interaction) }\end{array}$ & $\begin{array}{l}\text { Government initiative to make wifi } \\
\text { available } \\
\text { Private sector initiative to make wifi } \\
\text { available }\end{array}$ & $\begin{array}{l}\text { The capacity of countries / } \\
\text { regions to improve the } \\
\text { ability to } \\
\text { communicate one to } \\
\text { one or one to } \\
\text { many through } \\
\text { broadcasting content on } \\
\text { the internet }\end{array}$ \\
\hline $\begin{array}{l}\text { Technology literacy } \\
\text { (tools for life) }\end{array}$ & $\begin{array}{l}\text { Smartphone cost } \\
\text { Prepaid mobile phone costs } \\
\text { Postpaid mobile phone costs } \\
\text { E entertainment usage } \\
\text { Average fixed broadband latency } \\
\text { Network coverage } 2 \mathrm{~g} \\
\text { Network coverage } 3 \mathrm{~g} \\
4 \mathrm{~g} \text { network coverage }\end{array}$ & $\begin{array}{l}\text { The ability of the state to } \\
\text { provide information } \\
\text { technology } \\
\text { infrastructure so } \\
\text { that someone can adopt } \\
\text { technology, find out which } \\
\text { tools are appropriate, have } \\
\text { the ability to create new }\end{array}$ \\
\hline
\end{tabular}


Education attainment

Support for digital literacy

Average fixed broadband upload sped

Average fixed broadband download

speed

Level of web accessibility

Female digital skills training plan

Female STEM education

Wireless operator market share

Market share operator Broadband

Internet exchange point digital products / services / technology in a modern economy while also being able to think critically to solve economic / business problems through digital tools and to have knowledge of the development and maintenance of appropriate tools / technology.

1. Unfirming the data obtained by giving a score / ranking 1 to 3 assuming the value of $1=$ low, 2 = medium and 3 = high to get ordinal (non-parametric) data on each question item.

2. Conducting a test of Kruskal Wallis test to test comparison in non-parametric data that has more than two samples which is independent (independent of each other).

In conducting the Kruskal Wallis test, we use the SPSS software. With the proposed hypothesis, namely: H1: there is a difference in the level of digital literation between countries in ASEAN and H0: there is no difference in the level of digital literation between countries in ASEAN. With SPSS software, a significance value (P Value) will be obtained. If the significance value is less than 0.1 (critical limit) then $\mathrm{H} 1$ is accepted and $\mathrm{H} 0$ is rejected, conversely If the significance value is more than 0.1 (critical limit) then $\mathrm{H} 1$ is rejected and $\mathrm{H} 0$ is accepted.

3. Analyzing the reasons for differences or no differences in the trends.

\section{Results and Discussion}

\subsection{ASEAN 4.0 Revolution}

The concept of the industrial revolution 4.0 was first popularized by Professor Klaus Schwab, in his book, The Fourth Industrial Revolution. According to AT Kearney Company's report in 2017, industry evolution 4.0 is characterized by a cyber-physical system. Today, various industries in various parts of the world are starting to touch the virtual world, in the form of human, machine and data connectivity, all of which are everywhere. This term is known as the internet of things.

Tjandrawinata [7] revealed that the fourth industrial revolution has the potential to empower individuals and society, because it can create new opportunities for economic, social, and personal development. But it can also cause stunting and marginalization's of some groups, exacerbate social inequality, create new security risks, and can damage human relations. If we are to seize the opportunity and avoid this trap of the fourth industrial revolution, we must carefully consider the questions it raises.

In the scope of Southeast Asia, the dynamics resulting from the existence of the fourth industrial revolution is true. In the Philippines, for example, there are a number of projects 
initiated by Code Phil, a youth organization that aims to empower youth from developing countries, (in this case the Philippines) through digital literacy that can improve their lives which in turn will affect several aspects of life, especially social and economy. Based on Park, their projects include: 1). Type Phil, a free application that teaches basic how to type good and right. 2). Innovation Summit, an interactive and collaborative forum created so students from low economic circumstances can get to know technology-based careers, connect them with student mentors and Information and Communication Technology (ICT) experts, and invite them to collaborate on technology for local community. 3). Programming Curriculum, Code Phil organizes ICT teaching programs to schools in the Philippines. This shows that there is progress in society, marked by such an empowerment program caused by the fourth industrial revolution.

Meanwhile, with the fourth industrial revolution, Brunei Darussalam tries to improve infrastructure related to interconnectivity. Brunei Darussalam has considered broadband (a wide area network which is always online to be used to send and receive data) as a necessary service such as electricity or water. Therefore, Brunei Darussalam already has a strong foundation for the broadband era. On July 15, 2012, the Government of His Excellency Sultan and Yang Pertuan from Brunei Darussalam approved a budget of BND 230 million to initiate national broadband. In line with the vision of the Government of Brunei Darussalam, Telekom Brunei Berhad (TelBru), has its own initiative, starting the gradual construction of a fiber-to-the-home (FTTH) broadband network. The Authority for Info-communications Technology Industry (AITI) will be responsible for collecting and publishing statistics related to broadband based on a core list of standardized indicators by the International Telecommunication Union Partnership (AITI) that will track developments in infrastructure and broadband access, prices and affordability, and the use of broadband-capable services by individuals, businesses, schools and government departments then publish this information in the annual "Broadband State" report [8].

In Myanmar, managerial level executive skills in the IT field both personally and for work related to their vision for the future, digital literacy is needed. Workers who have digital literacy capabilities can encourage the development of the economic sector. Digital literacy is needed for work requirements in Myanmar. Given these requirements, it is possible for future training to be held for digital literacy.

While in Thailand, Open Educational Resources (OER) is held. OER is digital educational content, courses and material under an open license, which has increased opportunities for people who need to reuse learning material. Universal resources can cause negative effects due to careless use without really considering ethical aspects. OER must provide protection to the learning system to help evaluate resources for adequate use. The system must focus on searching and evaluating large amounts of resources to maximize digital literacy, in this case the ability to use digital materials including the ability to explain, access, evaluate manage, integrate, create and communicate digital content [9].

\subsection{Overview of ASEAN}

On August 8, 19675 countries namely Indonesia, Singapore, Malaysia, the Philippines and Thailand formed ASEAN through the signing of the Bangkok Declaration. This organization was formed on the basis of creating a safe, peaceful and prosperous region where in the 1960s the ASEAN region had the potential to be prone to conflict due to the ideological influence of the world's superpowers. 
ASEAN Community is the unity of society in Southeast Asia that has point of view to live in peace and bound in the development process. ASEAN compiles a program that directs the 3 pillars of political security, the economic pillar and the social cultural pillar. Currently, ASEAN members consist of 10 countries, namely Brunei Darussalam, Indonesia, Malaysia, Singapore, Thailand, Vietnam, Cambodia, the Philippines, Lao PDR and Thailand.

The following is our data of the countries' population in urban areas and state income in ASEAN.

Table 2. Total Population of Countries in ASEAN

\begin{tabular}{clcl}
\hline No. & \multicolumn{1}{c}{ Country name } & Population, Million & \multicolumn{1}{c}{ Information } \\
\hline 1 & Indonesia & 258,2 & Data is ranked from \\
2 & Philippines & 103.3 & the highest to the \\
3 & Vietnamese & 94.6 & lowest \\
4 & Thailand & 68.9 & \\
5 & Myanmar & 52.9 & \\
6 & Malaysia & 31.2 & \\
7 & Cambodia & 15.8 & \\
8 & Singapore & 5.6 & \\
\hline
\end{tabular}

Source: EIU, World Bank, 2017.

The country with the largest population is Indonesia and the lowest is Singapore, although the latter has the largest number of urban populations.

Table 3. Total Population in Urban Areas in ASEAN

\begin{tabular}{clcl}
\hline No. & Country name & $\begin{array}{c}\text { \% of Urban } \\
\text { Population }\end{array}$ & Information \\
\hline 1 & Singapore & 100 & Data is presented \\
2 & Malaysia & 75.5 & from high to low \\
3 & Indonesia & 54.5 & \\
4 & Thailand & 51.7 & \\
5 & Philippines & 44.2 & \\
6 & Myanmar & 34.7 & \\
7 & Vietnamese & 34.3 & \\
8 & Cambodia & 20.9 & \\
\hline
\end{tabular}

Source: EIU, World Bank, 2017.

Table 4. Gross National Product Countries in ASEAN

\begin{tabular}{clcl}
\hline No. & \multicolumn{1}{c}{ Country name } & $\begin{array}{c}\text { Nominal GDP of } \\
\text { USD Billion }\end{array}$ & Information \\
\hline 1 & Indonesia & 932.1 & Data is presented \\
2 & Thailand & 407.2 & from high to low \\
3 & Philippines & 304.5 & \\
4 & Singapore & 297.0 & \\
5 & Malaysia & 296,5 & \\
6 & Vietnamese & 201.4 & \\
7 & Myanmar & 65.8 & \\
8 & Cambodia & 20.0 & \\
\hline
\end{tabular}

Source: EIU, World Bank, 2017. 


\subsection{Comparisons of Digital Literacy Levels in ASEAN}

We conduct comparative tests to find out whether or not there are differences in the digital literacy levels of the ASEAN community. The proposed hypothesis is: H1: There is a difference in the level of digital literacy between 8 countries in ASEAN and H0: There is no difference in the level of digital literacy in 8 countries in ASEAN. The test uses the Kruskall Wallis Test comparative test with a significance of $10 \%$, this test is used because this test is appropriate to compare data on non-parametric statistics with ordinal data ranking (ranking) on independent samples in order to obtain test results as follows:

Table 5. Kruskall Wallis Test Results

\begin{tabular}{llcc}
\hline \multicolumn{3}{c}{ Ranks } & \\
\hline \multirow{3}{*}{ Digital } & Country & N & Mean Rank \\
Literacy & Cambodia & 5 & 15.60 \\
& Indonesia & 5 & 20.50 \\
& Malaysia & 5 & 19.20 \\
& Myanmar & 5 & 19.90 \\
& Philippines & 5 & 19.80 \\
& Singapore & 5 & 24.60 \\
& Thailand & 5 & 24.00 \\
& Vietnamese & 5 & 20.40 \\
& Total & 40 & \\
\hline
\end{tabular}

\begin{tabular}{lr}
\hline \multicolumn{2}{c}{ Statistic Tests ${ }^{\text {a, b }}$} \\
\hline \multicolumn{2}{c}{ Digital } \\
Literacy
\end{tabular}

We gather from this data that there is a significance value of 0.957 . These results are greater than the level of significance that has been determined that is $10 \%(0.1)$. When the significance value is greater than the significance level then $\mathrm{H} 1$ is rejected and H0 is accepted. The significance value of $10 \%$ means that this degree of trust is $90 \%$. The proposed hypotheses are: $\mathrm{H} 1$ : there is a difference in the level of digital literacy between 8 countries in ASEAN and H0: there is no difference in the level of digital literacy in 8 countries in ASEAN. From the SPPS calculation above it is known that the significance value is 0.957 where the value is greater than 0.1 . We conclude that our H1 is rejected and our H0 is accepted, which means there is no difference in the level of digital literacy among 8 countries in ASEAN.

Despite the absence of a difference, we can still measure the average levels of digital literacy. From our calculations, the highest average ranking was obtained by Singapore, while the lowest was Cambodia. We then rank these from highest to lowest, namely Singapore (24.6), Thailand (24.0), Indonesia (20.5), Vietnam (20.4), Myanmar (19.9), Philippines 
(19.80) Malaysia (19.20) and Cambodia (15.6). Digital literacy levels between one country and another in ASEAN are not too different from one another. This shows that digital literacy in ASEAN countries are almost at the same level. ASEAN community members possess almost the same ability to search for digital contents, produce them appropriately, utilize information, assess the truth of said information, manage the flow of information from the media and be able to adopt technology for certain situations.

Singapore is the country with the highest level of digital literacy compared with the average level, due to multiple individual subscription to more than one cellular provider, financial literacy through the Internet, reading news through the Internet, as well as accessing health information or education. There are $25-26$ out of 100 Singaporeans who subscribe to fixed-line broadband. Fixed-line broadband refers to the fixed subscription to high-speed access, Singaporeans feel safe to store their personal data online because there is legislation to protect their data. $65.4 \%$ Singaporeans are confident in government-provided websites and applications. In addition, the government initiated free Wi Fi hotspots. The state also has plans or strategies that address digital literacy for students and training for teachers, such as courses in Information and Communication Technology (ICT) skills.

We find that Cambodia has the lowest level of digital literacy compared with the average level, and there are several causes of this. The number of Cambodians who utilize financial information via the internet is low, whereas fixed-line broadband subscribers in the figure of 0.61 , which is low compared with other countries. Furthermore, laws on data protection are still unavailable and there is a lack of punishment imposed on offenders. Moreover, the government has not provided access to public Wi-Fi hotspots including in the cities, although private ones exists where Cambodians must pay for them. However, Cambodia has implemented a strategy that addresses digital literacy for students as well as training for teachers. Many people use the internet for entertainment purposes by generally using the $2 \mathrm{G}$ network to access the Internet.

\section{Conclusions}

There is no significant difference in the level of digital literacy between countries. This is evidenced by the results of the Kruskal Wallis Test calculations which show a significance number of 0.932 . The significance level is greater than the predetermined significance level of 0.1 . It concludes $\mathrm{HO}$ and $\mathrm{H} 1$ rejected, which shows that there is no significant difference in digital literacy among ASEAN countries. This shows that the digital literacy of countries in ASEAN shows almost the same level. Even so, the Kruskal Wallis Test calculation shows differences in average ranking even though the difference is not too large with Singapore as the country with the highest average ranking and Cambodia has the lowest average ranking.

\section{References}

[1] K. Chetty, L. Qigui, N. Gcora, J. Josie, L. Wenwei, and C. Fang, "Bridging the digital divide: measuring digital literacy," Econ. Open-Access, Open-Assessment E-Journal, vol. 12, no. 2018-23, pp. 1-20, 2018.

[2] P. Jiwon, "e-Inclusion: Access to Digital Literacy Education in Rural Philippines," 2017. [Online]. Available: https://cdn.nimbu.io/s/gcj6927/channelentries/16y45up/files/Session2JiwonPark.pdf?ar5cpiw. 
[Accessed: 06-Sep-2018].

[3] V. Juliswara, "Mengembangkan model literasi media yang berkebhinnekaan dalam menganalisis informasi berita palsu (hoax) di media sosial," J. Pemikir. Sosiol., vol. 4, no. 2, pp. 142-164, 2017.

[4] S. Kemp, "Digital, social \& mobile," We are Soc., 2015.

[5] A. Kearney, "The ASEAN Digital Revolution," 2017. .

[6] S. Gorard, Quantitative methods in social science research. A\&C Black. 2003.

[7] R. Tjandrawinata, "Industri 4.0: Revolusi Industri Abad Ini dan Pengaruhnya pada Bidang Kesehatan dan Bioteknologi.," 2015. [Online]. Available: https://www. researchgate. net/ publication/293695551_Industri_40_revolusi_industri_abad_ini_dan_pengaruhnya_pada_bidang_k esehatan_dan_bioteknologi. [Accessed: 26-Sep-2018].

[8] Ministry of Communication, "National Broadband Policy of Brunei Darussalam by Brunei Darussalam Ministry of Communication x International Telecommunication Union (ITU)," 2014. [Online]. Available: https://www.itu.int/en/ITU-D/Regional-Presence/AsiaPacific /Documents/P ublications-Reports/National_Broadband_Policy_Brunei_Darussalam.pdf. [Accessed: 09-Sep2018].

[9] S. Jongsermtrakoon and J. Nasongkhla, "A Group Investigation Learning System for Open Educational Resources to Enhance Student Teachers' Digital Literacy and Awareness in Information Ethics," 2015. [Online]. Available: http://www.ijiet.org/papers/611-T051.pdf. [Accessed: 09-Sep-2018]. 